\begin{tabular}{|c|c|c|}
\hline & Int.J.Curr.Microbiol.App.Sci (2021) 10(08): 692-696 & \\
\hline & $\begin{array}{l}\text { International Journal of Current Microbiology and Applied Sciences } \\
\text { ISSN: 2319-7706 Volume } \mathbf{1 0} \text { Number } \mathbf{0 8}(\mathbf{2 0 2 1 )} \\
\text { Journal homepage: http://www.ijcmas.com }\end{array}$ & $\begin{array}{l}50 \\
502\end{array}$ \\
\hline $\begin{array}{l}\text { EXCELLENT } \\
\text { PUBLISHERS }\end{array}$ & & whwe.jicmascom \\
\hline
\end{tabular}

\title{
Effect of Weed Management Practices on Yield and Economics of Linseed (Linum usitatissimum L.) in Vertisols of Chhattisgarh
}

\author{
Kanta Kumar*, A. S. Rajput and P. R. Mirjha \\ Department of Agronomy, D.K.S. College of Agriculture and Research Station, \\ Bhatapara, Chhattisgarh, India \\ *Corresponding author
}

\section{A B S T R A C T}

Keywords

Linseed crop, oilseed crop, herbicide, Linum usitatissimum $\mathrm{L}$

\section{Article Info}

Accepted:

25 July 2021

Available Online: 10 August 2021
The field experiment entitled "Effect of weed management practices on yield and economics of linseed (Linum usitatissimum L.) in Vertisols of Chhattisgarh" was carried out during rabi season of 2020-21; at the Instructional Cum Research Farm, DKS College of Agriculture and Research Station, Bhatapara. The experiment was laid out in Randomized Block Design with 3 replication and 12 treatments viz. $\mathrm{T}_{1}$ Weedy check, $\mathrm{T}_{2}-1$ hand weeding at $20 \mathrm{DAS}, \mathrm{T}_{3}-1$ hand hoeing at $20 \mathrm{DAS}+1$ hand weeding at $40 \mathrm{DAS}, \mathrm{T}_{4}$ - pendimethalin @ $0.90 \mathrm{~kg}$ a.i.ha ${ }^{-1}(\mathrm{PE}), \mathrm{T}_{5}$-pendimethalin@ $0.90 \mathrm{~kg}$ a.i. ha ${ }^{-1}(\mathrm{PE})+1$ hand weeding at $40 \mathrm{DAS}, \mathrm{T}_{6^{-}}$pendimethalin @ $0.90 \mathrm{~kg}$ a.i. ha ${ }^{-}$ ${ }^{1}(\mathrm{PE})+$ imazathypr @ 100g a.i. ha ${ }^{-1}(\mathrm{PoE}), \mathrm{T}_{7^{-}}$pendimethalin @ $0.90 \mathrm{~kg} \mathrm{a.i.ha}{ }^{-1}(\mathrm{PE})+$ isoproturon@1 kg a.i. ha ${ }^{-1}(\mathrm{PoE}), \mathrm{T}_{8^{-}}$pendimethalin@0.90 kg a.i. ha ${ }^{-1}(\mathrm{PE})+$ metsulfuron methyl @ 4g a.i. ha ${ }^{-1}(\mathrm{PoE}), \mathrm{T}_{9}$ - metsulfuron methyl @ 4g a.i. ha ${ }^{-1}(\mathrm{PoE})$, $\mathrm{T}_{10^{-}}$imazathypr @ $100 \mathrm{~g}$ a.i. ha ${ }^{-1}(\mathrm{PoE}), \mathrm{T}_{11}$ - isoproturon@ $1 \mathrm{~kg}$ a.i. $\mathrm{ha}^{-1}(\mathrm{PoE})$ and $\mathrm{T}_{12}$ - weed free. Linseed variety Indira alsi-32 (RLC-81) was sown on $09^{\text {th }}$ November, 2020 at $30 \times 10 \mathrm{~cm}$ spacing using $20 \mathrm{~kg}^{-1}$ seed ha ${ }^{-1}$ with recommended level of nutrients 60,30 and $30 \mathrm{~kg} \mathrm{~N}, \mathrm{P}_{2} \mathrm{O}_{5} \& \mathrm{~K}_{2} \mathrm{O}$ ha $^{-1}$ respectively. Crop was harvested on $24^{\text {th }}$ February, 2021. The result showed that the weed free $\left(\mathrm{T}_{8}\right)$ recorded highest yield, which was statistically at par with 1 hand hoeing at $20 \mathrm{DAS}+1$ hand weeding at 40 DAS $\left(\mathrm{T}_{3}\right)$. Highest benefit: cost ratio was recorded in pendimethalin @ $0.90 \mathrm{~kg}$ a.i. ha ${ }^{-}$ ${ }^{1}(\mathrm{PE})+$ metsulfuron methyl @ $4 \mathrm{~g}$ a.i. ha ${ }^{-1}(\mathrm{PoE})\left(\mathrm{T}_{8}\right)$ followed by metsulfuron methyl @ $4 \mathrm{~g}$ a.i. ha ${ }^{-1}(\mathrm{PoE})\left(\mathrm{T}_{9}\right)$. Weedy check $\left(\mathrm{T}_{1}\right)$ was the most inferior treatment which recorded $875 \mathrm{~kg} \mathrm{ha}^{-1}$ and $1326 \mathrm{~kg} \mathrm{ha}^{-1}$ grain and straw yield respectively.

\section{Introduction}

Linseed (Linum usitatissimum L.) is a major oilseed crop in India, it is primarily cultivated during the rabi season. It has high oil value with large amount of fibre, carbohydrates and fat. The productivity of linseed is very low in India as well as in Chhattisgarh due to various agronomic reasons; weed infestation is one of the major limiting factors in production. Weed species infesting in linseed vary according to the agro-ecosystem of the growing region. 
Weeds compete with the linseed crop during early growing stage resulting reduction yield, initial growth period of 20-45 days is very critical for weed control. Season long weed competition has been found to reduce linseed yield to the extent of $30-40 \%$ during rabi season (Mahere et al., 2000). Physical or mechanical methods of weed management are conventional methods of weed control in linseed. Many times 2-3 manual weedings are required to keep the crop weeds free. Hand weeding is expensive because it is not only time consuming but labour intensive also. However, the extra benefit of giving more aeration and soil moisture conservation may not be overlooked. But, with a rising labour shortage the discovery of the possibility of herbicide weed control in linseed needs recognition. Identifying of a selective and cost effective herbicide can be a good alternative to giving a weed free environment for such an important during early growth period of crop.

\section{Materials and Methods}

The field experiment was conducted at the Research-cum-Instructional Farm, Dau Kalyan Singh College of Agriculture and Research Station, Bhatapara, Chhattisgarh during rabi season of 2020-21.

Experimental site is located in South Eastern region of Chhattisgarh at $21^{\circ} 43^{\prime} \mathrm{N}$ latitude and $81^{\circ} 59^{\prime}$ E longitude with an attitude of 273 $\mathrm{m}$ above mean sea level (MSL), Experimental site have clay texture (Vertisols) soil with $\mathrm{pH}$ of 7.7, organic carbon content of $0.30 \%$ and available $\mathrm{N}, \mathrm{P}_{2} \mathrm{O}_{5}$ and $\mathrm{K}_{2} \mathrm{O}$ content of 112.7 , 12.73 and $384.0 \mathrm{~kg} \mathrm{ha}^{-1}$ respectively. The total rainfall received during the crop growth period was $30.2 \mathrm{~mm}$, relative humidity ranged between $59.7 \%$ in $45^{\text {th }}$ standard week to $51.2 \%$ in $9^{\text {th }}$ standard week, with the mean of weekly maximum and minimum temperature 27.2 to $35.2^{\circ} \mathrm{C}$ and 9.2 to $18.0^{\circ} \mathrm{C}$ respectively. The treatment consist \& of 12 weed management practices viz. $\mathrm{T}_{1}-$ Weedy check, $\mathrm{T}_{2}-1$ hand weeding at $20 \mathrm{DAS}, \mathrm{T}_{3}-1$ hand hoeing at $20 \mathrm{DAS}+1$ hand weeding at 40 DAS, $\mathrm{T}_{4}$ - pendimethalin @ $0.90 \mathrm{~kg}$ a.i.ha ${ }^{-1}$ (PE) $\mathrm{T}_{5}$-pendimethalin @ $0.90 \mathrm{~kg}$ a.i. ha ${ }^{-1}$ (PE) +1 hand weeding at 40 DAS, T6 pendimethalin @ $0.90 \mathrm{~kg}$ a.i. ha ${ }^{-1}(\mathrm{PE})+$ imazathypr @100g a.i. ha ${ }^{-1}(\mathrm{PoE}), \mathrm{T}_{7}$ pendimethalin@0.90 kg a.i. ha ${ }^{-1}(\mathrm{PE})+$ isoproturon @ $1 \mathrm{~kg}$ a.i. $\mathrm{ha}^{-1}(\mathrm{PoE}), \mathrm{T}_{8^{-}}$ pendimethalin @ $0.90 \mathrm{~kg}$ a.i. ha ${ }^{-1}(\mathrm{PE})+$ metsulfuron methyl @ 4g a.i. ha ${ }^{-1}(\mathrm{PoE}), \mathrm{T}_{9}$ metsulfuron methyl @ 4g a.i. ha ${ }^{-1}(\mathrm{PoE}), \mathrm{T}_{10^{-}}$ imazathypr@100 g a.i. ha ${ }^{-1}(\mathrm{PoE}), \mathrm{T}_{11}$ isoproturon@1 kg a.i. ha ${ }^{-1}(\mathrm{PoE})$, and $\mathrm{T}_{12}$ weed free.

Experiment was laid out in Randomized Block Design with three replications. Indira alsi-32 variety was sown on $9^{\text {th }}$ November, with inter and row spacing of 30 and $10 \mathrm{~cm}$ respectively. The field was fertilized with $\mathrm{N}, \mathrm{P}_{2} \mathrm{O}_{5}, \mathrm{~K}_{2} \mathrm{O} @$ 60,30 and $30 \mathrm{~kg} \mathrm{ha}^{-1}$ respectively. Half of $\mathrm{N}$ (30 kg), full of $\mathrm{P}_{2} \mathrm{O}_{5}$ and $\mathrm{K}_{2} \mathrm{O}$ were applied during final land preparation before sowing. Remaining of $\mathrm{N}(30 \mathrm{~kg})$ was applied as first top dressing at $30 \mathrm{DAS}$.

All the herbicides were applied as per the protocol of application time using knapsack sprayer. The observation on seed yield, stover yield and biological yield was recorded from the net plot and converted to $\mathrm{kg} \mathrm{ha}^{-1}$.

Harvest index was determined using the formulas economic yield $\left(\mathrm{kg} \mathrm{ha}^{-1}\right) /$ biological yield $\left(\mathrm{kg} \mathrm{ha}^{-1}\right) \times 100$ as suggested by Donald (1962). Cost of cultivation was calculated based on prevailing labour wages at farm and price of inputs and operations.

For the calculation of gross returns, minimum support price was taken for grain and local market price was used for stover. The Benefit : Cost ratio was worked out on the basis of net returns per unit cost of cultivation. 


\section{Results and Discussion}

Effect of weed management practices on yield of linseed crop

The linseed yield was significantly influenced by weed management practices (Table 1). Weed free $\left(T_{12}\right)$ treatment recorded highest grain yield, stover yield and biological yield of $1175 \mathrm{~kg} \mathrm{ha}^{-1}, 2027.10 \mathrm{~kg} \mathrm{ha}^{-1}$ and $3202.1 \mathrm{~kg}$ $\mathrm{ha}^{-1}$ followed by 1 hand hoeing at $20 \mathrm{DAS}+$ 1hand weeding at 40 DAS $\left(\mathrm{T}_{3}\right)$ of $1144.6 \mathrm{~kg}$ $\mathrm{ha}^{-1}, 1955 \mathrm{~kg} \mathrm{ha}^{-1}$ and $3082 \mathrm{~kg} \mathrm{ha}{ }^{-1}$ respectively. The lowest yield recorded with weedy check $\left(\mathrm{T}_{1}\right)$ of $451.6 \mathrm{~kg} \mathrm{ha}^{-1}, 874.5 \mathrm{~kg}$ $\mathrm{ha}^{-1}$ and $1326.2 \mathrm{~kg} \mathrm{ha}^{-1}$ in grain yield, stover yield and biological yield respectively. Drastic reductions of Linseed yield due to higher competition of weeds with crop for growth factors (moisture, light, nutrients and space) in weedy check have also been reported by Jain and Jain (2016). Harvest index of the crop were also significantly influence by weed management practices (Table 1).

Highest values (38.49\%) for harvest index were recorded with post emergence application of Metsulfuron methyl@ 4g a.i. $\left(\mathrm{T}_{8}\right)$. Weedy check $\left(\mathrm{T}_{1}\right)$ recorded the lowest harvest index (34.05\%).

Table.1 Yield $\left(\mathrm{kg} \mathrm{ha}^{-1}\right)$ and harvest index $(\%)$ of linseed as influenced by different methods of weed management

\begin{tabular}{|c|c|c|c|c|}
\hline Treatment & $\begin{array}{c}\text { Seed } \\
\text { yield } \\
\left(\text { kgha }^{1}\right)\end{array}$ & $\begin{array}{c}\text { Stover } \\
\text { yield (kg } \\
\left.\text { ha }^{-1}\right)\end{array}$ & $\begin{array}{c}\text { Biological } \\
\text { yield (kg } \\
\left.\mathrm{ha}^{-1}\right)\end{array}$ & $\begin{array}{c}\text { harvest } \\
\text { index }(\%)\end{array}$ \\
\hline$T_{1}-$ Weedy check & 452 & 875 & 1326 & 34.05 \\
\hline $\mathrm{T}_{2}-1$ hand weeding at $20 \mathrm{DAS}$ & 797 & 1387 & 2184 & 36.50 \\
\hline $\begin{array}{l}\mathrm{T}_{3} \text { - } 1 \text { hand hoeing at } 20 \mathrm{DAS}+1 \text { hand } \\
\text { weeding at } 40 \mathrm{DAS}\end{array}$ & 1127 & 1955 & 3082 & 36.58 \\
\hline $\mathrm{T}_{4}$ - Pendimethalin @ $0.90 \mathrm{~kg}$ a.i. ha ${ }^{-1}$ (PE) & 836 & 1454 & 2290 & 36.50 \\
\hline $\begin{array}{l}\mathrm{T}_{5} \text { - Pendimethalin @ } 0.90 \mathrm{~kg} \text { a.i. } \mathrm{ha}^{-1}(\mathrm{PE})+1 \\
\text { hand weeding at } 40 \mathrm{DAS}\end{array}$ & 903 & 1572 & 2475 & 36.50 \\
\hline $\begin{array}{l}\text { T}_{6} \text { - Pendimethalin @ } 0.90 \mathrm{~kg} \text { a.i. ha }{ }^{-1}(\mathrm{PE})+ \\
\text { imazathypr @ } 100 \mathrm{~g} \text { a.i. ha }\end{array}$ & 936 & 1629 & 2566 & 36.50 \\
\hline $\begin{array}{l}\text { T }_{7} \text { - Pendimethalin @ } 0.90 \text { kg a.i.ha }{ }^{-1} \\
\text { (PE)+Isoproturon @ } 1 \mathrm{~kg} \text { a.i. ha }{ }^{-1} \text { (PoE) }\end{array}$ & 904 & 1572 & 2476 & 36.50 \\
\hline $\begin{array}{l}\text { T8 - Pendimethalin @ } 0.90 \text { kg a.i. ha }{ }^{-1}(\mathrm{PE})+ \\
\text { Metsulfuron methyl @ } 4 \mathrm{~g} \text { a.i.ha }{ }^{-1}(\mathrm{PoE})\end{array}$ & 1053 & 1883 & 2936 & 35.87 \\
\hline T9 - Metsulfuron methyl@ 4g a.i. ha ${ }^{-1}(\mathrm{PoE})$ & 942 & 1505 & 2446 & 38.49 \\
\hline $\mathrm{T}_{10}$-Imazathypr@100g a.i.ha ${ }^{-1}(\mathrm{PoE})$ & 855 & 1488 & 2344 & 36.50 \\
\hline $\mathrm{T}_{11}$-Isoproturon@1kg a.i.ha ${ }^{-1}(\mathrm{PoE})$ & 803 & 1398 & 2201 & 36.50 \\
\hline $\mathbf{T}_{12}-$ Weed free & 1175 & 2027 & 3202 & 36.69 \\
\hline SEm \pm & 17.71 & 27.09 & 42.22 & 0.427 \\
\hline $\mathrm{CD}(P=0.05)$ & 50.61 & 77.43 & 120.69 & 1.222 \\
\hline
\end{tabular}

*PE- Pre emergence, PoE- Post emergence 
Table. 2 Cost of cultivation, gross return, net return and benefit: cost ratio as influenced by different methods of weed management.

\begin{tabular}{|c|c|c|c|c|}
\hline Treatment & $\begin{array}{c}\text { Cost of } \\
\text { cultivation } \\
\left(\operatorname{Rs~ha}^{-1}\right)\end{array}$ & $\begin{array}{c}\text { Gross } \\
\text { returns } \\
\left(\operatorname{Rs~ha}^{-1}\right)\end{array}$ & $\begin{array}{c}\text { Net } \\
\text { returns } \\
\left(\mathrm{Rs} \mathrm{ha}^{-1}\right)\end{array}$ & $\begin{array}{c}\text { B:C } \\
\text { Ratio }\end{array}$ \\
\hline$T_{1}$ - Weedy check & 14825 & 21200 & 6375 & 0.43 \\
\hline $\mathrm{T}_{2}-1$ hand weeding at $20 \mathrm{DAS}$ & 18875 & 37252 & 18377 & 0.97 \\
\hline $\begin{array}{l}\mathrm{T}_{3}-1 \text { hand hoeing at } 20 \mathrm{DAS}+ \\
1 \text { hand weeding at } 40 \mathrm{DAS}\end{array}$ & 22925 & 53464 & 30539 & 1.33 \\
\hline$T_{4}$ - Pendimethalin @ 0.90 kg a.i. ha ${ }^{-1}(\mathrm{PE})$ & 16112 & 39059 & 22947 & 1.42 \\
\hline $\begin{array}{l}\text { T }_{5} \text { - Pendimethalin @ } 0.90 \mathrm{~kg} \text { a.i. ha }{ }^{-1}(\mathrm{PE})+ \\
1 \text { hand weeding at } 40 \text { DAS }\end{array}$ & 20162 & 42222 & 22060 & 1.09 \\
\hline $\begin{array}{l}\text { T}_{6} \text { - Pendimethalin @ } 0.90 \mathrm{~kg} \text { a.i. ha } \\
\text { imazathypr } @ 100 \mathrm{~g} \text { a.i. ha } \mathrm{ha}^{-1}(\mathrm{PoE})\end{array}$ & 17501 & 43764 & 26263 & 1.50 \\
\hline $\begin{array}{l}\mathrm{T}_{7} \text { - Pendimethalin @ } 0.90 \mathrm{~kg} \text { a.i. ha }{ }^{-1}(\mathrm{PE})+ \\
\text { Isoproturon@ } 1 \mathrm{~kg} \text { a.i. ha }{ }^{-1}(\mathrm{PoE})\end{array}$ & 17581 & 42237 & 24656 & 1.40 \\
\hline $\begin{array}{l}\text { T8 -Pendimethalin @ } 0.90 \text { kg a.i. ha }{ }^{-1}(\mathrm{PE})+ \\
\text { Metsulfuron methyl @ } 4 \mathrm{~g} \text { a.i. ha }{ }^{-1}(\mathrm{PoE})\end{array}$ & 16399 & 49268 & 32869 & 2.00 \\
\hline $\mathrm{T}_{9}$ - Metsulfuron methyl @ 4g a.i. ha ${ }^{-1}(\mathrm{PoE})$ & 15112 & 43880 & 28768 & 1.90 \\
\hline $\mathrm{T}_{10^{-}}$Imazathypr @ $100 \mathrm{~g}$ a.i. ha ${ }^{-1}(\mathrm{PoE})$ & 16215 & 39978 & 23763 & 1.47 \\
\hline $\mathrm{T}_{11}$ - Isoproturon@ 1 kg a.i. ha ${ }^{-1}(\mathrm{PoE})$ & 16294 & 37548 & 21254 & 1.30 \\
\hline$T_{12}-$ Weed free & 26975 & 54902 & 27927 & 1.04 \\
\hline SEm \pm & - & 818.80 & 818.80 & 0.046 \\
\hline $\mathrm{CD}(P=0.05)$ & - & 2340.24 & 2340.24 & 0.133 \\
\hline
\end{tabular}

*PE- Pre emergence, PoE- Post emergence

Effect of weed management practices on economics of linseed crop

Data on the economics of linseed as influenced by weed management practices are shown in table 2. Among the weed management practices, weed free $\left(\mathrm{T}_{12}\right)$ is recorded maximum cost of cultivation and gross returns of $26975.0 \mathrm{Rs} \mathrm{ha}^{-1}$ and $54902 \mathrm{Rs}$ $\mathrm{ha}^{-1}$ respectively, which was statistically at par with 1 hand hoeing at 20 DAS +1 hand weeding at $40 \mathrm{DAS}\left(\mathrm{T}_{3}\right)$. This might be due to higher price of labour charge by weeding which involved more number of labour for manual weeding to create weed free condition. Weedy check $\left(T_{1}\right)$ incurred minimum cost of cultivation (14825 Rs. ha ${ }^{-1}$ ) though gave lowest gross returns of $54902 \mathrm{Rs} \mathrm{ha}^{-1}$. Similar findings also reported by Dwivedi and puhup (2019).

Post emergence application of pendimethalin @ $0.90 \mathrm{~kg}$ a.i. ha ${ }^{-1}+$ metsulfuron methyl @ 4g a.i. ha ${ }^{-1}\left(\mathrm{~T}_{8}\right)$ being at par with 1 hand hoeing at 20 DAS + 1hand weeding at 40 DAS $\left(T_{3}\right)$ fetched highest net returns (32869 Rs ha' ${ }^{-1}$ ). Weedy check $\left(\mathrm{T}_{1}\right)$ recorded lowest net returns $\left(6375 \mathrm{~kg} \mathrm{ha}^{-1}\right)$. Similar findings noted by Dwivedi and Puhup (2019). Benefit: cost ratio was noted significantly higher (2.0) with preemergence application of pendimethalin @ $0.90 \mathrm{~kg}$ a.i. ha ${ }^{-1}$ followed by application of metsulfuron methyl @ $4 \mathrm{~g}$ a.i. ha ${ }^{-1}$ as post emergence, although this treatment was statistically at par with metsulfuron methyl @ $4 \mathrm{~g}$ a.i. $\mathrm{ha}^{-1}(\mathrm{PoE})\left(\mathrm{T}_{9}\right)$. Thus it can be 
concluded that application of pendimethalin @ $0.90 \mathrm{~kg}$ a.i. ha ${ }^{-1}(\mathrm{PE})+$ metsulfuron methyl @ $4 \mathrm{~g}$ a.i. ha ${ }^{-1}(\mathrm{PoE})\left(\mathrm{T}_{8}\right)$ and metsulfuron methyl @ $4 \mathrm{~g}$ a.i. ha $^{-1}(\mathrm{PoE})\left(\mathrm{T}_{9}\right)$ was found the promising treatment in term of higher seed yield and $\mathrm{B}: \mathrm{C}$ ratio for enhancing the productivity and profitability of linseed.

Weed free $\left(\mathrm{T}_{12}\right)$ treatment produced the highest seed yield of linseed (1175 kg ha ${ }^{-1}$ ) followed by 1 hand hoeing at 20 DAS +1 hand weeding at 40 DAS $\left(\mathrm{T}_{3}\right)\left(1144 \mathrm{~kg} \mathrm{ha}^{-1}\right)$ and pendimethalin @ $0.90 \mathrm{~kg}$ a.i. ha ${ }^{-1}(\mathrm{PE})+$ metsulfuron methyl @ 4g a.i. ha ${ }^{-1}(\mathrm{PoE})\left(\mathrm{T}_{8}\right)$ $\left(1053 \mathrm{~kg} \mathrm{ha}^{-1}\right)$. Weedy check $\left(\mathrm{T}_{1}\right)$ treatment produced the lowest grain yield of $\left(451 \mathrm{~kg} \mathrm{ha}^{-}\right.$ $\left.{ }^{1}\right)$. Increased grain and straw yields were primarily due to maintenance of weed free environment, especially during critical growth stages of crop, which reduce crop weed competition allowed for better growth and development of linseed crop resulting in higher seed yield.

\section{References}

Acharya, S. S., Nirala, R. B. P., Roychowdhury, A., Ghosh, M. and Haque, M. 2017. Bio-efficacy of herbicides against complex weed flora in linseed Indo-gangetic plain of Bihar.

Research on crops 18(1): 49-56.

Donald, 1962. In search of yield. Journal of Australian Agricultural Science 28: 171-178.

Dwivedi, S. K. and Puhup, C. S. 2019. Weed dynamics, growth pattern, yield and economics of linseed under different weed management practices. Indian Journal of Weed Science 51(1): 36-39.

Jain, D. N. and Jain, V. 2016. Weed management with pre and post emergence herbicides in liseed (Linum usitatissimum L.). World Weeds 5(12): 41-45.

Mahere, J., Yadav, P. K. and Sharma, R. S. 2000. Chemical weed control in linseed withspecial reference to Cuscuta. Indian journal of weed science 32: 216-17.

Mishra, J. S., Singh, V. P. and Yaduraju, N. T. 2003. Bio-efficacy and economics of herbicidal weed control in irrigated linseed (Linum usitatissimum L.). Indian Journal of Weed Science 35(1\&2): 154-155.

Vavilov, N. I. 1951. The origin, variation, immunity and breeding of cultivated plants, $1-366$.

\section{How to cite this article:}

Kanta Kumar, A. S. Rajput and Mirjha, P. R. 2021. Effect of Weed Management Practices on Yield and Economics of Linseed (Linum usitatissimum L.) in Vertisols of Chhattisgarh. Int.J.Curr.Microbiol.App.Sci. 10(08): 692-696. doi: https://doi.org/10.20546/ijcmas.2021.1008.078 